\section{France's peers overseas}

SIR - Your amusing, but pessimistic, view (Nature 352, 176; 1991) of the outcome of our international inquiry into the reputations of the professors employed in the French university system is incomplete.

Your readers should know of the full scope of our attempt to establish a clear, acceptable and (we hope) accurate evaluation system for French university research and graduate studies. We have a scientific advisory council of 25 members, half of them from outside France, including several Nobel and Fields laureates, and chaired by Jean Marie Lehn. The council reviews ministry policy every six months, publishes its opinions and formulates recommendations on longer-term scientific policy.

Thirty groups, each of approximately 15 experts, review all proposals for contract money, advise on the right to award master's or doctoral degrees and evaluate candidates for the newly established prime d'encadrement doctoral et de recherche. (These are awards of an annual bonus of FF30,000 for four years to those who have been particularly successful in teaching and directing doctoral students and in producing and publishing innovative research.) The expert committees are similar in several respects to those established a few years ago to evaluate British science and to rank all British university departments. In addition, hundreds of French and foreign experts contribute evaluations of particular projects by mail.

Seven scientific directors and their staff use all this material to prepare the minister's decisions. The results are discussed with the universities. The principal outcome is a four-year contract between the ministry and each university, committing the state to a minimum level of funding. All evaluations and grants are made public.

The creation of this system has undoubtedly been eased because of the high priority given by the French Government to education and research. One obvious result is that the funds available to universities for research and doctoral studies have risen by more than 30 per cent over the past three years, reaching FF2,900 million in 1992. (The global budget, including the salaries of professors and other staff, is in excess of FF11,000 million.)

Our further attempt to provide experts with quantitative and external qualitative data must be judged against that background. We are now attempting to use citation indices and have also launched the worldwide inquiry campaign mentioned in your leading article. We do not intend to use the responses directly in making decisions about the funding or promotion of individuals. We want to assemble the answers by department, university and discipline so as to form an opinion of the reputation that costly state-financed scientific research projects have earned abroad. We want to see ourselves as others see us.

Everybody knows that there is no perfect method of evaluating, even in broad terms, the quality of continuing research. Even if the many hundreds of responses to our letter include some along the lines that you predicted, the great majority have been independent straightforward opinions of the reputation of French science in particular fields, and as such have been useful and useable. We shall make a synthesis available as soon as possible.

I should like to take this opportunity to thank the hundreds of scientists outside France who have taken the time and trouble to provide us with serious and unprejudiced responses.

VINCENT COURTILLOT

Ministère de l'Education Nationale,

de la Jeunesse et des Sports

61-65 Rue Dutot,

75732 Paris Cedex 15, France

\section{Reductionism}

SIR - Douglas B. Kell (Nature 350, 268; 1991) and Roland Dixon (Nature 351, 685 ; 1991) have commented on the ignorance of students concerning reductionism. Kell suggests that the subject needs investigation.

In 1980, in the Australian National University, 61 advanced or graduate students of zoology, all competent, answered a series of questions on the philosophy of biology. More than half held all biology to be ultimately reducible to physical science; but only seven were able to name this doctrine. Twelve of their teachers were invited to answer the questions; of the seven who did so, five accepted the principle of explanatory reduction but only one could recall its name ${ }^{1}$.

The inability to name a concept is not in itself important. More notable is the ignorance, revealed by those students, of a number of issues of great practical significance. Their ignorance reflected their experience of university study. Most universities concentrate on producing graduates who know little outside the very narrow range of their special studies; and such a training encourages an unthinking reduction of complex phenomena to the concepts of a single subject such as biochemistry or genetics. Socially important problems can usually be solved only by applying the methods and findings of several disciplines ${ }^{2}$. When, therefore, such specialists try to apply their knowledge in practice, they meet questions that they are not equipped to answer.

The handicap imposed by specialism is especially evident when the attempt is made to apply the methods or findings of the natural sciences to questions concerning human societies ${ }^{3,4}$. There is therefore much to be said for encouraging students and their teachers to study the uses and limitations of explanatory reduction; but attempts to introduce transdisciplinary university courses, in which this could be done, still arouse much hostility 5

\section{Australian National University}

Box 4, GPO, Canberra, ACT 2601

Australia

1. Barnett S.A., Brown V.A. \& Coton H. Studies in Higher Education 8, 23-32 (1983)

2. Ashby $\mathrm{E}$ in The Sociology of Science (ed Halmos, P.) (University of Keele, Staffordshire, 1972)

Kitcher P. Vaulting Ambition (MIT Press, Cambridge, Massachusetts, 1985).

4. Barnett S.A. Biology and Freedom (Cambridge University Press, 1988).

Barnett S.A. \& Brown V.A. Interdisciplinary Science Reviews 8, 294-296 (1983).

\section{Powdered milk}

SIR - James Vickers (Nature 353, 103; 1991 ) is obviously not a reader of The Times (18 July), nor of the Church Times (26 July), or he would have seen that Nestlé has addressed the issues on which the Church of England General Synod reached its extraordinary decision. Moreover, unless he is a member of the Synod, he will not have seen the letter addressed to all its members by $\mathrm{Mr}$ Peter Blackburn, UK chairman and managing director of Nestlé, before it began its debate. Blackburn said that, in the interest of truth and fairness, the Synod would want to be in possession of all the facts, and went on: "We assure you that we have nothing to hide and would more than welcome an objective review of our record, including consultation with the World Health Organisation [WHO] and governments of countries in which our company operates".

As your readers will know, the Synod chose to ignore this offer. It is alarming to see members of the scientific community mouthing activist slogans as Vickers does. Where does he get the idea that WHO "has been condemning Nestlé's activities in this area for years"? Or that donating infant formula is designed "to create a market for the product among nursing mothers"?

May I suggest that instead of accepting activist propaganda at face value he does what any serious scientist should do, and finds out the facts.

Nestlé SA, Avenue Nestlé 55

F. X. Perroud $\mathrm{CH}-1800$ Vevey, Switzerland 